\title{
Quality in e-Government accounting services: A model of relationships between e-service quality dimensions and behaviors
}

\author{
Cemil KUZEY ${ }^{*}$,M. Sait DINC**, Ali H. GUNGORMUS ${ }^{* * * *}$, Lokman INCIRKUS ${ }^{* * * * *}$
}

Received: April 20, 2019

Revised: May 14, 2019

Accepted: May 20,2019.

\begin{abstract}
The purpose of this study is to examine the relationship between perceptions held by accountants regarding the e-service quality dimensions of the e-government website in connection with their behavioral and praising intentions. Using the survey method, 203 responses were collected from accountants in Turkey. A partial least square structural equation model was constructed to test both the reliability and validity of the measurement as well as the structural model. The results showed that several e-service quality sub-dimensions such as graphical quality, emotional benefits, and ease of use and control have a positive and significant impact on behavioral intention and praising intention. The study did not find support for the possible effect of layout clarity upon behavioral intention and praising intention.
\end{abstract}

Keywords: e-service quality; accountants; partial least square structural equation model.

JEL Classification Codes: M38

UDC: 331.07

DOI: https://doi.org/10.17015/ejbe.2019.023.04

\footnotetext{
* Arthur J. Bauernfeind College of Business, Murray State University, Murray, USA. Email: cemilkuzey@gmail.com

** American University of the Middle East, Kuwait. Email: Muhammet.Dinc@aum.edu.kw

*** Independent scholar, Koblenz, Germany. Email: a.h.gungormus@gmail.com

**** Independent Scholar, Istanbul, Turkey. Email: incirkuslokman@gmail.com 


\section{Introduction}

Recent technological developments in the computer and internet world have brought change and transformation in both the public and the private sectors. The main purpose for using new technologies such as new apps in these sectors has been to enhance effectiveness of service deliveries. In this regard, public organizations have started to use information communication technologies, in particular e-services, in order to enhance their organizational efficiency and to improve their service quality standards on behalf of citizens. Since early 2000, public organizations in Turkey have also begun utilizing e-services for their service deliveries. Because the provision of e-services through the WebPages of each public organization had begun posing technical problems to citizens, all e-services of the public organizations in Turkey have been provided through e-government (www.turkiye.gov.tr) since 2008. In the following years, citizens hesitated when using e-government, due to technical problems as well as their habitual ways of using the traditional services. However, demand for the use of the e-government service has increased in recent years as a result of the fact that Turkish citizens have become aware of improvements in the service and ease of usage.

Accounting professionals have also been influenced by these technological improvements in Turkey. Among the changes created by these developments is the fact that traditional accounting applications have been transferred to information technology, with data registrations being input into computers. This has produced quick, reliable accounting processes, helping both accountants and customers access accounting information swiftly. With the advent of e-government online services being more widely used, online taxation services are now being utilized through integrating internet-based technologies. Following this, tax returns have begun being approved through online services. Finally, all offline processes have been transformed into online taxation e-processes by adding e-bills to the online services. The Ministry of Finance in Turkey has transformed all offline processes into online e-processes in order to minimize tax evasion, to collect taxes swiftly and to decrease the workloads undertaken by the tax office.

Since accountants represent many roles: as individuals, business representatives, and free-lance professionals, thereby comprising the major users of the egovernment web site, a need has evolved for a website that conforms to rigorous quality standards in order to facilitate user compliance with fiscal obligations. Hence, the overriding objective of the e-government website is to simplify the transaction process for taxpayers and/or accountants. With this concern in mind, the purpose of this study was to examine the relationship between the perceptions of accountants on the e-service quality dimensions of the e-government website, with a focus upon their behavioral and praising intentions. 


\section{Conceptual Framework and Hypotheses Development}

\subsection{Conceptualizing E-service quality}

The quality of electronic services (QES) was described by Zeithaml, Parasuraman, and Malhotra (2000) as "the extent to which a website facilitates efficient and effective shopping, purchasing, and delivery" (p. 11). Although this is one of the most cited definitions, it has been criticized by some scholars (Fassnacht \& Koese, 2006; Gummerus et al., 2004) for two main reasons. First, they found that the definition created by Zeithaml, Parasuraman, and Malhotra was too narrow because of its concentration on online shopping. Second, the "website" was specified as the only reference object of quality. The website is very important because it can be useful for research which focuses upon website related issues, but QES needs to encompass more than the website. Therefore, to be specific, QES can be defined as the degree to which an electronic service is able to effectively and efficiently fulfill relevant customer needs (Fassnacht \& Koese, 2006).

In the last two decades, there have been several studies contributing to the theoretical advancement of service quality significantly (see Brady \& Cronin, 2001; Dabholkar et al., 1996; Dabholkar et al., 2000; Dagger et al., 2007; Rust \& Oliver, 1994). Within these conceptualizations, some studies have focused on service quality from hierarchical and multi-dimensional perspectives. The suggestions from these works were that the construct should be viewed as being of a higher order that has specific dimensions related to sub-dimensions (e.g. Carman, 1990; Dabholkar et al., 1996; Brady \& Cronin, 2001). In this context, "hierarchical" means that sub-dimensions are treated as first-order constructs, whereas dimensions are treated as being second-order constructs of service quality. For example, in Rust and Oliver (1994)'s conceptualization of service quality, three dimensions were used: service environment (physical ambiance), service delivery (interaction), and service product (outcome). Brady and Cronin (2001)'s study, which was based upon the work of Rust and Oliver (1994) and Dabholkar et al. (1996), introduced a hierarchical conceptualization of service quality with three dimensions: environment quality, delivery quality, and outcome quality, with nine related subdimensions.

In the past five years, e-service quality research has received significant attention. The main part of this research has extended the theoretical and empirical works into the service quality literature. However, only a limited section of these studies has adapted a hierarchical, multi-dimensional service quality modeling approach. For example, Fassnacht and Koese (2006) adapted Brady and Cronin's (2001) service quality conceptualization by incorporating three quality dimensions: a) environment quality, related to the appearance of the user interface; b) delivery quality, belonging to the customer-website interaction during service usage; and c) outcome quality, referring to the results obtained by the customer after delivery of the service. These three dimensions contained nine sub-dimensions as first-order 
factors in order to capture the e-service quality construct. To date, Fassnacht and Koese (2006) have been the only researchers adapting a hierarchical approach to capturing e-service quality evaluations at the sub-dimension level and the dimension level, as well as using a separate overall evaluation of e-service quality.

\subsection{Environment Quality}

Fassnacht and Koese (2006) divided the environment of websites into two sub dimensions: graphic quality and clarity of layout. Graphic quality captures the visual representation of relevant user interface elements, while clarity of layout refers to the usefulness of the design structure of the user interface. In Santos (2003)'s exploratory study, elements such as graphics, pictures, and images were deemed to be providing improvements in quality. Structure and layout were articulated as the helpful organization and presentation of content and information placed on the website. Therefore, elements such as simplicity, clearness, and consistency were considered to be providing attractiveness within the structure and layout.

Regarding the website role in e-service quality, Chen et al. (2009) paid attention to three dimensions which might affect consumer usage intention; a user-friendly interface provided by the website which provides ease of usage, search capability, rich content and interactivity. The environment quality was anticipated to improve business performance. Lee and Kozar (2006), in their study focused on the website quality effect on e-business success by using four important dimensions: information quality, service quality, systems quality, and vendor-specific quality.

\subsection{Delivery Quality}

E-services offer benefits through their interface efficiency. The way in which the interface enables service providers to develop options for their customers can be considered to be quality delivery. Quality delivery contains dimensions which make it easier for the user, who benefits from the offered services through attractiveness of selection, information quality, ease of use, and technical quality. Ease of use is defined as the degree to which the functionality of the user interface facilitates the customer's retrieval of the electronic service (Fassnacht \& Koese, 2006). These dimensions play important roles in the customer service usage process, which comprise steps such as seeking information, selection between options, and carrying out transactions (Fassnacht \& Koese, 2006; Carlson \& O'Cass, 2011). Jeong et al. (2003) measured website efficiency through information accuracy, clarity, completeness, ease of use, navigational quality, and color combinations. From among the different segments, the respondents' ability to find requested information clearly, ease of use, and navigational quality were perceived as enabling quality usage. Additionally, information accuracy, information completeness, and color combinations were considered to be dimensions that differentiate specific websites from others. 


\subsection{Outcome Quality}

Emotional benefit was defined as "the degree to which using the service arouses positive feelings" whereas functional benefit can be defined as "match between service and its value proposition" (Fassnacht \& Koese, 2006). Lai (1995) also defined the emotional (affective) benefit as being the "product's capacity to arouse feelings or affective states" (305). In the same study, functional quality was defined as the product's capability in terms of functionality, utility, and physical performance. In the study of Fassnacht and Koese (2006), it was seen that the three sub dimensions of e-service quality had differing contributions. The further functional benefits leading to the final outcome was remarkable. In the study of Carlson and O'Cass (2011), these two dimensions also exhibited strong, yet differing constructs. Thus, these dimensions deserve to be measured and evaluated differently.

Most prior research focused on the relationship between e-service quality, customer satisfaction, and behavioral intention, which included word-of-mouth communication, revisiting the site, and purchase intentions (Gounaris et al., 2010). There were also some studies revealing the relationship between trust, satisfaction and e-loyalty (Lim, 2015; Ladhari \& Lecrec, 2013). Within the context of accounting, some studies examined the e-service quality dimensions and satisfaction in relation to accountants. For example, a study conducted with 351 certified accountants found that some dimensions of e-service quality such as empathy, tangibility and convenience contributed towards their satisfaction (Carlos, Macedo, \& Monteiro, 2007). With regard to e-government service quality, several studies were conducted recently (Papadomichelaki \& Mentzas, 2012; Sá, Rocha, \& Cota, 2016a; Sá, Rocha, \& Cota, 2016b; Janita \& Miranda, 2018). However, some of these studies were done in Turkey (Kurfali et al., 2017; Uyar, 2010; Dinc et al., 20XX). Based upon the literature mentioned above, the following hypotheses were proposed for the present study:

Hypothesis 1a: Graphical Quality has a significant and positive effect on emotional Benefits.

Hypothesis $1 b$ : Graphical Quality has a significant and positive effect on ease of use and control.

Hypothesis 1c: Graphical Quality has a significant and positive effect on behavioral intention.

Hypothesis 1d: Graphical Quality has a significant and positive effect on praising intention.

Hypothesis 2a: Layout clarity has a significant and positive effect on emotional benefits.

Hypothesis $2 b$ : Layout clarity has a significant and positive effect on ease of use and control.

Hypothesis 3c: Layout clarity has a significant and positive effect on behavioral intention. 
Hypothesis 4d: Layout clarity has a significant and positive effect on praising intention.

Hypothesis 3a: Emotional Benefits has a significant and positive effect on behavioral intention.

Hypothesis 3b: Emotional Benefits has a significant and positive effect on praising intention.

Hypothesis 3a: Ease of use and control has a significant and positive effect on behavioral intention.

Hypothesis $3 b$ : Ease of use and control has a significant and positive effect on praising intention.

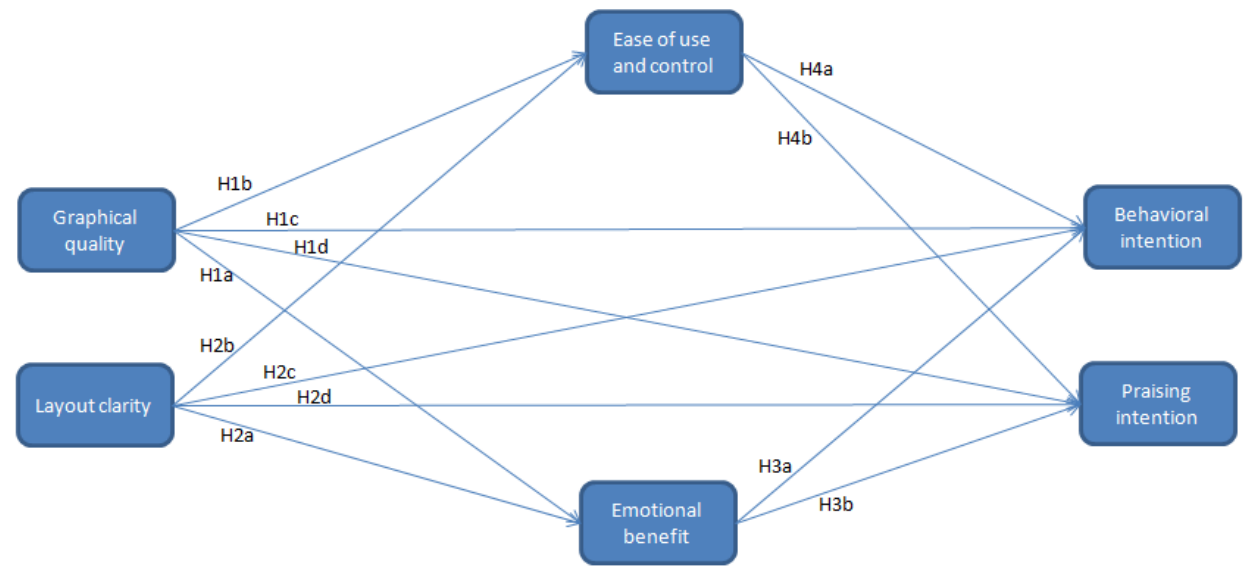

Figure 1: Proposed model

\section{Research methodology}

\subsection{Measure and sampling}

Multi-item scales were modified and adapted from previous studies in English language sources. The constructs were measures using the 5-point Likert scales, in which 1 represents "strongly disagree" and 5 represents "strongly agree". Partial Least Square Structural Equation Modeling (PLS-SEM) analysis was employed to test the proposed hypothetical relationship.

The scales that were used to measure the quality of the e-service sub-dimensions were modified and adapted from Fassnacht and Koese (2006). These subdimensions were graphical quality $(G Q)$, layout clarity $(L C)$, emotional benefits (EB), and ease of use and control (EUC). Behavioral intention (BI) and praising intention (PI), adapted from Dabholkar et al. (2000), measured behavioral intentions including the likelihood of revisiting the website in future as well as recommending the website to others. The back translation (Brislin, 1970) method was used since the language of the adapted scales was in English. The objective of this method is to acquire the equivalence of translated survey items (Turkish) to the original 
language (English). The direct translation method has been used widely whereby a bilingual translator translates the survey items from English to Turkish. The direct translation method is not recommended a) if the translator is not fluent in the base language as well as the respondent's language, and/or b) if the translator is not familiar with both cultures. Back translation is therefore recommended in order to eliminate any errors produced within the direct translation method. For this study, the survey items were translated from English by a bilingual expert, with the translated items being re-translated back into the original language by a different bilingual expert. As a result of this procedure, translation errors were identified and corrected before a draft version of the survey items was prepared. The draft questionnaire was checked by marketing professors. After following these procedures, the survey items were ready to send to the target group.

The target population was projected to be accountants working in the biggest provinces in Turkey such as Istanbul, Ankara, and Izmir. Accounting offices were contacted online with an explanation of the objective of the study. The initial sample size was 500 , out of which 400 agreed to contribute to the study. The respondents were informed that there was no right or wrong answer and assured that their responses would remain anonymous so as not to be linked to them individually or to their firms. This helped participants reduce possible anxiety resulting from a concern that his or her knowledge could be assessed unfavorably by an audience (Bordia et al., 2006). In the end, 203 participants out of the 400 who had initially agreed to participate completed the questionnaires. Due to high missing values, five cases were eliminated which resulted in 188 for the data analysis. Therefore, the final sample size was 188 with a $51 \%$ response rate.

The characteristics of the sample are provided in Table $1.84 \%$ were male and $16 \%$ were female. Also, the ages of $30.3 \%$ were between 39 and 45 years old, $28.7 \%$ were between 32 and 38 , while only $2.1 \%$ were younger than $25.73 \%$ of the participants held undergraduate degrees, $54 \%$ held a certified public accountant license, and almost 53\% of the respondents had over 15 years' experience. In addition, $44 \%$ of the participants owned the CPA office, while $30 \%$ comprised staff in a private organization. Finally, General Directors were $50 \%$ of the respondents, $18 \%$ were accounting specialists, $14 \%$ were Directors of Finance, and $10 \%$ were Accounting Managers.

Initially, a collinearity assessment was pursued. The set of predictor constructs for each subpart of the structural model were examined separately. According to the proposed model, graphic quality and layout clarity jointly explained the ease of use and control and emotional benefit. Likewise, graphic quality, layout clarity, ease of use and control, and emotional benefit were the predictor variables for both behavioral intention as well as praising intention. The collinearity analysis revealed that the variance inflation factor (VIF) values ranged between 1.75 and 3.71, which were all less than the threshold value of 10 (Hair et al., 2010). Therefore, there were no significant levels of collinearity between each set of constructs. 
Cemil Kuzey, M. Sait DINC, Ali H. Gungormus, \& Lokman Incirkus

Table 1: Descriptive Statistics

\begin{tabular}{|c|c|c|c|}
\hline Variables & & Frequency & Percent \\
\hline \multirow[t]{3}{*}{ Gender } & Female & 30 & 16.0 \\
\hline & Male & 158 & 84.0 \\
\hline & Total & 188 & 100.0 \\
\hline \multirow{7}{*}{ Age } & $<25$ & 4 & 2.1 \\
\hline & $25-31$ & 27 & 14.4 \\
\hline & $32-38$ & 54 & 28.7 \\
\hline & $39-45$ & 57 & 30.3 \\
\hline & $46-52$ & 25 & 13.3 \\
\hline & $>52$ & 21 & 11.2 \\
\hline & Total & 188 & 100.0 \\
\hline \multirow[t]{6}{*}{ Education } & Ph.D. & 2 & 1.1 \\
\hline & Master & 37 & 19.7 \\
\hline & Undergraduate & 137 & 72.9 \\
\hline & Associate & 2 & 1.1 \\
\hline & High school & 10 & 5.3 \\
\hline & Total & 188 & 100.0 \\
\hline \multirow{6}{*}{$\begin{array}{l}\text { License of } \\
\text { authorization }\end{array}$} & No license & 17 & 9.0 \\
\hline & CPA (Certified Public Accountant) & 101 & 53.7 \\
\hline & CPA trainee & 16 & 8.5 \\
\hline & CPA-Independent auditor & 48 & 25.5 \\
\hline & Sworn-in Certified Public Accountant & 6 & 3.2 \\
\hline & Total & 188 & 100.0 \\
\hline \multirow[t]{6}{*}{ Experience } & $1-5$ years & 21 & 11.2 \\
\hline & $6-10$ years & 30 & 16.0 \\
\hline & $11-15$ years & 38 & 20.2 \\
\hline & $16-20$ years & 43 & 22.9 \\
\hline & $20+$ years & 56 & 29.8 \\
\hline & Total & 188 & 100.0 \\
\hline \multirow[t]{11}{*}{ Position } & Staff at an audit firm & 3 & 1.6 \\
\hline & Staff at a public institution & 4 & 2.1 \\
\hline & Internal and external accounting in my own office & 1 & 0.5 \\
\hline & At my own CPA-Audit office & 9 & 4.8 \\
\hline & At my own CPA office & 82 & 43.6 \\
\hline & At my own Sworn-in Certified Public Accountant office & 5 & 2.7 \\
\hline & Staff at a private institution & 57 & 30.3 \\
\hline & Staff at a CPA office & 19 & 10.1 \\
\hline & Unemployed & 2 & 1.1 \\
\hline & Staff at a Sworn-in Certified Public Accountant office & 6 & 3.2 \\
\hline & Total & 188 & 100.0 \\
\hline \multirow{7}{*}{$\begin{array}{l}\text { Title in the } \\
\text { company }\end{array}$} & Director General & 94 & 50.0 \\
\hline & Director of Finance & 27 & 14.4 \\
\hline & Deputy Director of Accounting & 4 & 2.1 \\
\hline & Accounting Manager & 19 & 10.1 \\
\hline & Accounting Supervisor & 11 & 5.9 \\
\hline & Accounting Specialist & 33 & 17.6 \\
\hline & Total & 188 & 100.0 \\
\hline
\end{tabular}


The twenty-three items were subject to factor analysis based on Smart PLS. Table 2 shows the factor loadings. The factor loadings were all above the suggested threshold value of .70, therefore convergent validity was met (Chin, 1998). Since all the items were above the recommended value, none were removed from the analysis. The discriminant validity was satisfied since each item had a higher factor loading on its own construct comparing to the other constructs. Each item had the highest loading than the cross loading on the row level as well as column level. The Cronbach's alpha values ranged between .83 and .92, and the composite reliability values ranged between .89 and .94 (Table 4). These results indicated that the reliability of the constructs was also satisfied, since they were all above the recommended threshold value of .70 .

Table 2: Measurement model's factor loadings

\begin{tabular}{lllllll}
\hline Items & GQ & LC & EB & EUC & BI & PI \\
\hline GQ1 & .88 & .56 & .36 & .45 & .44 & .43 \\
GQ2 & .92 & .64 & .51 & .58 & .51 & .54 \\
GQ3 & .89 & .56 & .45 & .57 & .52 & .45 \\
LC1 & .58 & .87 & .46 & .56 & .53 & .45 \\
LC2 & .58 & .94 & .58 & .69 & .52 & .52 \\
LC3 & .64 & .93 & .60 & .69 & .57 & .55 \\
EB1 & .41 & .42 & .84 & .59 & .62 & .57 \\
EB2 & .44 & .53 & .85 & .64 & .58 & .57 \\
EB3 & .30 & .49 & .76 & .62 & .49 & .51 \\
EB4 & .47 & .53 & .82 & .76 & .62 & .59 \\
EUC1 & .51 & .57 & .74 & .88 & .61 & .59 \\
EUC2 & .48 & .63 & .69 & .86 & .58 & .52 \\
EUC3 & .55 & .58 & .66 & .85 & .61 & .60 \\
EUC4 & .53 & .59 & .66 & .82 & .64 & .61 \\
EUC5 & .46 & .63 & .63 & .83 & .57 & .54 \\
BI1 & .43 & .52 & .60 & .62 & .86 & .63 \\
BI2 & .42 & .53 & .60 & .61 & .77 & .62 \\
BI3 & .49 & .43 & .52 & .56 & .82 & .63 \\
BI4 & .47 & .47 & .63 & .58 & .86 & .75 \\
PI1 & .51 & .52 & .60 & .62 & .76 & .90 \\
PI2 & .48 & .51 & .57 & .58 & .70 & .90 \\
PI3 & .43 & .45 & .64 & .61 & .70 & .89 \\
PI4 & .48 & .52 & .64 & .62 & .70 & .89 \\
\hline Not & .52 &
\end{tabular}

Notes: GQ: Graphical Quality; LC: Layout Clarity; EB: Emotional Benefits; EUC: Ease of Use and Control; Bl: Behavioral Intention; PI: Praising Intention

The same six constructs were also subjected to confirmatory factor analysis (CFA) using the maximum likelihood method in order to test the measurement model for assessing the construct validity. The fit measures as well as the measurement model results are shown in Table 3. The CFA provided a good fit as recommended by $\mathrm{Hu}$ and Bentler (1999) with $\chi_{(\mathrm{df}=208)}^{2}=378.61, p<.001 ; \chi^{2} / \mathrm{df}=1.82$; goodness of fit index $(\mathrm{GFI})=.85$; normed fit index $(\mathrm{NFI})=.90$; comparative fit index 
$(\mathrm{CFI})=.95$; relative fit index $(\mathrm{RFI})=.87$; incremental fit index $(\mathrm{IFI})=.95$; Tucker-Lewis index $(T L I)=.94$; and root mean square error of approximation (RMSEA) $=.06$. These fit indices indicated a sufficient evidence of good models. In addition, the convergent validity was satisfied since the items were statistically significantly loaded to their respective latent variable

\section{Table 3: Measurement model results}

\begin{tabular}{cccc}
\hline Latent Variable & Items & Standardized Coefficients & t-Value \\
\hline \multirow{3}{*}{ GQ } & GQ1 & .81 & - \\
& GQ2 & .89 & 13.63 \\
& GQ3 & .82 & 12.43 \\
\hline \multirow{3}{*}{ LC } & LC1 & .91 & - \\
& LC2 & .91 & 18.42 \\
& LC3 & .78 & 14.00 \\
\hline \multirow{3}{*}{ EB } & EB1 & .83 & - \\
& EB2 & .71 & 9.46 \\
& EB3 & .73 & 10.96 \\
& EB4 & .71 & 10.49 \\
\hline \multirow{3}{*}{ EUC } & EUC1 & .79 & - \\
& EUC2 & .76 & 11.43 \\
& EUC3 & .82 & 11.39 \\
& EUC4 & .82 & 12.63 \\
& EUC5 & .85 & 13.20 \\
\hline \multirow{3}{*}{ BI } & BI1 & .81 & - \\
& BI2 & .74 & 12.28 \\
& BI3 & .72 & 10.51 \\
& BI4 & .78 & 11.81 \\
\hline & PI1 & .84 & - \\
PI & PI2 & .84 & 15.33 \\
& PI3 & .84 & 13.37 \\
& PI4 & .87 & 14.12 \\
\hline
\end{tabular}

GQ: Graphical Quality; LC: Layout Clarity; EB: Emotional Benefits; EUC: Ease of Use and Control; BI: Behavioral Intention; PI: Praising Intention. $\chi_{(d f=208)}^{2}=378.61, p<.001$; $\chi^{2} / d f=1.82 ; \mathrm{GFI}=.85 ; \mathrm{NFI}=.90 ; \mathrm{CFI}=.95 ; \mathrm{RFI}=.87 ; \mathrm{IFI}=.95 ; T L I=.94 ; R M S E A=.06$.

\subsection{Measurement Model Analysis:}

The association between a latent variable and its corresponding indicators was modeled as either reflective or formative. Each latent variable demonstrated reflective indicators to assess the construct validity in this study. According to Podsakoff et al. (2003), the reflective approach is chosen when the variation in the construct causes variation in the item measure; dropping an item from the model should not affect the construct; and the indicators are correlated with the latent variable at a high level. In determining individual item reliability, construct reliability and discriminant validity should be checked. Table 4 shows the 
descriptive statistics, average variance extracted values, composite reliability, correlation coefficients, and the square root of average variance extracted value at the diagonal of the matrix of each latent variable in order to assess the discriminant validity, reliability, and convergent validity (Hair et al., 2010). Individual item reliability was already assessed since all item loadings were above.70 (Chin, 1998). The internal consistency was determined using composite reliability. The composite reliability values ranged between .89 and .94 , which are all above the suggested value of .70 (Nunally, 1987). Average variance extracted (AVE) and the square root of AVE values versus the correlations coefficients of the latent variables were used to determine the discriminant validity (Fornell \& Larcker, 1981). The values of AVE were above the recommended threshold value of .50, which indicated that the given latent variable was different from the other variables. Also, the square root of AVE placed on the diagonal of the correlation matrix was greater than the correlation coefficients of the latent variables placed off-diagonal. Thus, the results indicated that discriminant validity was satisfied.

\section{Table 4: Descriptive statistics, correlation analysis and reliability measures of the variables}

\begin{tabular}{llllllllll}
\hline & Mean & S.D. & Variables & $\mathbf{1}$ & $\mathbf{2}$ & $\mathbf{3}$ & $\mathbf{4}$ & $\mathbf{5}$ & $\mathbf{6}$ \\
\hline 1 & 3.67 & .98 & GQ & .90 & & & & & \\
2 & 3.42 & 1.02 & LC & $.65^{* *}$ & .91 & & & & \\
3 & 3.56 & .87 & EB & $.49^{* *}$ & $.59^{* *}$ & .94 & & & \\
4 & 3.59 & .90 & EUC & $.59^{* *}$ & $.70^{* *}$ & $.79^{* *}$ & .96 & & \\
5 & 3.89 & .82 & BI & $.55^{* *}$ & $.59^{* *}$ & $.70^{* *}$ & $.71^{* *}$ & .95 & \\
6 & 3.76 & .96 & PI & $.52^{* *}$ & $.55^{* *}$ & $.68^{* *}$ & $.67^{* *}$ & $.79^{* *}$ & .97 \\
\hline & & & C.R. & .93 & .94 & .89 & .93 & .90 & .94 \\
& & AVE & .80 & .83 & .67 & .72 & .69 & .80 \\
& & $\alpha$ & .88 & .90 & .83 & .90 & .85 & .92 \\
\hline
\end{tabular}

Notes: GQ: Graphical Quality; LC: Layout Clarity; EB: Emotional Benefits; EUC: Ease of Use and Control; BI: Behavioral Intention; PI: Praising Intention; C.R: Composite Reliability; AVE: Average Variance Extracted; S.D.: Standard Deviation; $\alpha$ : Cronbach's Alpha; the elements on the diagonal are the square root of AVE, while the elements on the off-diagonals are the correlations between latent variables; ${ }^{* *} p<.01$.

\subsection{Structural equation modeling}

The structural equation modeling results are shown in Table 5. Partial least square (PLS) structural equation modeling (SEM) was employed for testing the hypothetical relationships due to the relatively small sample size and its resulting advantages of having some restrictive assumptions. For this, Smart PLS v. 2 with the bootstrapping resampling method was used in order to test the statistical significance of the associations (Ringle et al., 2005). To obtain standard errors as well as t-statistics for calculating the coefficients, bootstrapping with a recommended value of 5000 resamples was used (Henseler et al., 2009). 
The explained variance $\left(R^{2}\right)$ reveals the explanatory power of a structural equation model. According to Hair et al. (2010), an $\mathrm{R}^{2}$ value of .20 is considered high in PLSSEM. The results indicated that the explanatory powers of the dependent latent variables were all high, since the explained variance of emotional benefit was .38, ease of use and control was .53, behavioral intention was .58, and praising intention was .54

Table 5: Structural equation modeling results

\begin{tabular}{lllllll}
\hline Hypothesis & & Paths & & Beta & t-Statistics & Results \\
\hline H1a & GQ & $\rightarrow$ & EB & $.18^{* *}$ & 2.09 & Support \\
H1b & GQ & $\rightarrow$ & EUC & $.23^{* *}$ & 2.61 & Support \\
H1c & GQ & $\rightarrow$ & BI & $.15^{* *}$ & 2.33 & Support \\
H1d & GQ & $\rightarrow$ & PI & $.16^{* *}$ & 2.17 & Support \\
H2a & LC & $\rightarrow$ & EB & $.48^{* * *}$ & 5.74 & Support \\
H2b & LC & $\rightarrow$ & EUC & $.56^{* * *}$ & 6.89 & Support \\
H2c & LC & $\rightarrow$ & BI & .07 & 1.12 & Not supported \\
H2d & LC & $\rightarrow$ & PI & .05 & .82 & Not supported \\
H3a & EB & $\rightarrow$ & BI & $.36^{* * *}$ & 4.13 & Support \\
H3b & EB & $\rightarrow$ & PI & $.38^{* * *}$ & 3.12 & Support \\
H4a & EUC & $\rightarrow$ & BI & $.28^{* *}$ & 2.58 & Support \\
H4b & EUC & $\rightarrow$ & PI & $.24^{* *}$ & 2.05 & Support \\
\hline
\end{tabular}

GQ: Graphical Quality; LC: Layout Clarity; EB: Emotional Benefits; EUC: Ease of Use and Control; BI: Behavioral Intention; PI: Praising Intention; ${ }^{* *} p<.05 ;{ }^{* *} p<.01 ; R_{E B}^{2}=.38, R_{E U C}^{2}=.53, R_{B I}^{2}=.58, R_{P I}^{2}=$ .54

The results showed a positive, statistically significant effect between graphical quality and emotional benefit $(\beta=.18, p<.05)$, ease of use/control $(\beta=.23, p<.05)$, behavioral intentions $(\beta=.15, p<.05)$, and praising intention $(\beta=.16, p<.05)$. Thus, $\mathrm{H} 1 \mathrm{a}, \mathrm{H} 1 \mathrm{~b}, \mathrm{H} 1 \mathrm{c}, \mathrm{H} 1 \mathrm{~d}$ were all supported. In addition, layout clarity had a positive and highly significant impact on emotional benefit $(\beta=.48, p<.01)$ and ease of use/control $(\beta=.56, p<.01)$, while it did not show a statistically significant association with either behavioral intention or praising intention. Therefore, $\mathrm{H} 2 \mathrm{a}$ and $\mathrm{H} 2 \mathrm{~b}$ were supported, and $\mathrm{H} 2 \mathrm{C}$ and $\mathrm{H} 2 \mathrm{~d}$ were not supported. Moreover, the results indicated that emotional benefit had a positive and highly significant relationship with behavioral intention $(\beta=.36, p<.01)$ and praising intention $(\beta=.38$, $\mathrm{p}<.01$ ). Thus, $\mathrm{H} 3 \mathrm{a}$ and $\mathrm{H} 3 \mathrm{~b}$ were also supported. Finally, ease of use/control had a positive and significant impact in behavioral intention $(\beta=.28, p<.05)$ and praising intention $(\beta=.24, p<.05)$ which indicated that $\mathrm{H} 4 \mathrm{a}$ and $\mathrm{H} 4 \mathrm{~b}$ were supported.

\section{Discussion}

Building on Fassnacht and Koese (2006) and Carlson and O'Cass (2011)'s original theoretical framework of e-service quality, this study examined the effect of the perceptions made by accountants about the dimensions of e-service quality located on the e-government website upon their behavioral and praising intentions. Consistent with the research hypotheses, it was found that graphical quality, 
emotional benefits, and ease of use and control each have a positive and significant impact upon behavioral intention and praising intention. The study did not find support for the effect of layout clarity on either of behavioral intention and praising intention. The implications of the study are highlighted in the following paragraphs.

In this study, accountants revealed a high perception of quality with regard to graphical quality $(M=3.67 ; S D=0.98)$, layout clarity $(M=3.42 ; S D=1.02)$, emotional benefits $(M=3.56 ; S D=0.87)$, and ease of use and control $(M=3.59 ; S D$ $=0.90$ ), indicating that the e-service dimensions of the e-government website were evaluated positively by accountants. Furthermore, this study went further by analyzing the extent to which the aforementioned dimensions are related to the accountants' behavioral intention and praising intention. The results indicated that graphical quality, layout clarity, emotional benefits, and ease of use and control were strongly and positively correlated with behavioral intention and praising intention. This result is important, since it provides an opportunity to reconsider the provision of e-government online services.

The results of this study have particular relevance for both marketing theory and practice. From the theoretical point of view, this study provides an important contribution for measurements of e-service quality, especially for e-government services. It proposes new items while validating Fassnacht and Koese (2006) and Carlson and O'Cass (2011)'s e-service quality dimensions within the specific context of online e-government dimensions. The results displayed support for the impacts of e-service quality dimensions such as graphical quality, emotional benefits, and ease of use and control on the behavioral and praising intentions of accountants. From a practical standpoint, this study evaluated the opinions of accountants who are necessarily heavy users of the e-government website. Based upon these opinions from those who responded, the services provided by e-government would benefit greatly by enhancing the layout clarity of the environment quality dimension.

\section{Limitations and Future Research}

There are several limitations to the study. Firstly, the geographic limitation of the study (only three large cities were studied) did not allow for generalization of results. Future studies should collect data from accountants working in other large size cities. Second, self-reported issues may constitute a limitation in this sensitive study. However, the survey was designed and administered carefully in order to minimize this potential limitation. The final limitation for this research is the inadequate amount of previous literature. Future studies might include several variables such as satisfaction concerning e-service quality, behavioral intention and praising intention relationships. 
Cemil Kuzey, M. Sait DINC, Ali H. Gungormus, \& Lokman Incirkus

\section{References}

Bordia, P., Irmer, B.E., \& Abusah, D. (2006). Differences in sharing knowledge interpersonally and via databases: The role of evaluation apprehension and perceived benefits. European Journal of Work and Organizational Psychology, 15(3), 262-280. https://doi.org/10.1080/13594320500417784

Brady, M. \& Cronin, J. (2001). Some new thoughts on conceptualizing perceived service quality: a hierarchical approach. Journal of Marketing, 65(3), 34-49. https://doi.org/10.1509/jmkg.65.3.34.18334

Brislin, R. W. (1970). Back-translation for cross-cultural research. Journal of cross-cultural psychology, 1(3), 185-216. https://doi.org/10.1177/135910457000100301

Carlos Pinho, J., Macedo, I.M., \& Monteiro, A.P. (2007). The impact of online SERVQUAL dimensions on certified accountant satisfaction: The case of taxation services. EuroMed Journal of Business, 2(2), 154-172. https://doi.org/10.1108/14502190710826031

Carlson, J. \& O'Cass, A. (2011). Developing a framework for understanding e-service quality, its antecedents, consequences, and mediators. Managing Service Quality: An International Journal, 21(3), 264-286. https://doi.org/10.1108/09604521111127965

Carman, J.M. (1990). Consumer perceptions of service quality: an assessment of the SERVQUAL dimensions. Journal of Retailing, 66(1), 33-55.

Chen, S.C., Chen, H.H., \& Chen, M.F. (2009). Determinants of satisfaction and continuance intention towards self-service technologies. Industrial Management \& Data Systems, 109(9), 1248-1263. https://doi.org/10.1108/02635570911002306

Chin, W.W. (1998). The partial least squares approach for structural equation modeling, in Marcoulides, G.A. (Ed.), Modern methods for business research, Lawrence Erlbaum Associates, Mahwah, NJ, 295-336.

Dabholkar, P., Shepherd, C., \& Thorpe, D. (2000). A comprehensive framework for service quality: an investigation for critical conceptual and measurement issues through a longitudinal study. Journal of Retailing, 76(2), 139-73. https://doi.org/10.1016/S00224359(00)00029-4

Dabholkar, P., Thorpe, D., \& Rentz, J. (1996). A measure of service quality for retail stores: scale development and validation, Journal of the Academy of Marketing Science, 24(1), 3-16. https://doi.org/10.1007/BF02893933

Dagger, T., Sweeney, J.C., \& Johnson, L.W. (2007). Health-SQ: developing a multidimensional health service quality scale. Journal of Service Research, 10(2), 123-42. https://doi.org/10.1177/1094670507309594

Dinc, M.S., Kuzey, C., Gungormus, A.H., \& Atalay, B. (2019). Burnout among accountants: the role of organisational commitment components. European Journal of International Management. Forthcoming, https://www.doi.org/10.1504/EJIM.2019.10017013.

Fassnacht, M. \& Koese, I. (2006). Quality of electronic services: Conceptualizing and testing a hierarchical model. Journal of service research, 9(1), 19-37. https://doi.org/10.1177/1094670506289531

Fornell, C. \& Larcker, D.F. (1981). Evaluating structural equation models with unobservable variables and measurement error. Journal of Marketing Research, 18(1), 39-50. https://doi.org/10.1177/002224378101800104 
Gounaris, S., Dimitriadis, S., \& Stathakopoulos, V. (2010). An examination of the effects of service quality and satisfaction on customers' behavioral intentions in e-shopping. Journal of services marketing, 24(2), 142-156. https://doi.org/10.1108/08876041011031118

Gummerus, J., Veronica L., Minna P., \& Allard V. (2004). Customer Loyalty to Content-Based Websites: The Case of an Online Health-Care Service. Journal of Services Marketing, 18(3), 175-86. https://doi.org/10.1108/08876040410536486

Hair, J.F., Anderson, R.E., Tatham, R.L., \& Black, W.C. (2010). Multivariate Data Analysis with Readings, 7th Ed. Englewood Cliffs, Prentice Hall, NJ.

Henseler, J., Ringle, C.M., \& Sinkovics, R.R. (2009). The use of partial least squares path modeling in international marketing (ed. by Sinkovics, R. R. \& PN, G.), pp. 277-319. Emerald, Bingley

Hu, L.T. \& Bentler, P.M. (1999). Cutoff criteria for fit indexes in covariance structure analysis: Conventional criteria versus new alternatives. Structural equation modeling: a multidisciplinary journal, 6(1), 1-55. https://doi.org/10.1080/10705519909540118

Janita, M. S., \& Miranda, F. J. (2018). Quality in e-Government services: A proposal of dimensions from the perspective of public sector employees. Telematics and Informatics, 35(2), 457-469. https://doi.org/10.1016/i.tele.2018.01.004

Kurfalı, M., Arifoğlu, A., Tokdemir, G., and Paçin, Y. (2017). Adoption of e-government services in Turkey. Computers in Human Behavior, 66, 168-178. https://doi.org/10.1016/j.chb.2016.09.041

Lai, A.W. (1995). Consumer values, product benefits and customer value: a consumption behavior approach, ACR North American Advances.

Lee, Y. and Kozar, K. A. (2006). Investigating the effect of website quality on e-business success: An analytic hierarchy process (AHP) approach. Decision support systems, 42(3), 1383-1401. https://doi.org/10.1016/i.dss.2005.11.005

Nunnally, J. (1978). Psychometric Theory, 2nd ed., McGraw-Hill, New York, NY.

Papadomichelaki, X., \& Mentzas, G. (2012). e-GovQual: A multiple-item scale for assessing egovernment service quality. Government information quarterly, 29(1), 98-109. https://doi.org/10.1016/i.giq.2011.08.011

Podsakoff, P.M., MacKenzie, S.B., Lee, J.Y., \&Podsakoff, N. P. (2003). Common method biases in behavioral research: A critical review of the literature and recommended remedies. Journal of Applied Psychology, 88, 879-903. https://doi.org/10.1037/0021-9010.88.5.879

Ringle, C., Wende, S., \& Will, A. (2005). Smart-PLS Version 2.0 M3. University of Hamburg.

Rust, R.T. \& Oliver, R.L. (1994). Service quality: insights and managerial implications from the frontier, in Rust, R. and Oliver, R. (Eds), Service Quality: New Directions in Theory and Practice, Sage, Thousand Oaks, CA.

Sá, F., Rocha, Á., \& Cota, M. P. (2016a). Potential dimensions for a local e-Government services quality model. Telematics and Informatics, 33(2), 270-276. https://doi.org/10.1016/i.tele.2015.08.005

Sá, F., Rocha, Á., \& Cota, M. P. (2016b). From the quality of traditional services to the quality of local e-Government online services: A literature review. Government Information Quarterly, 33(1), 149-160. https://doi.org/10.1016/i.giq.2015.07.004 
Cemil Kuzey, M. Sait DINC, Ali H. Gungormus, \& Lokman Incirkus

Santos, J. (2003). E-service quality: a model of virtual service quality dimensions. Managing Service Quality: An International Journal, 13(3), 233-246. https://doi.org/10.1108/09604520310476490

Uyar, A. (2010). Cost and management accounting practices: a survey of manufacturing companies. Eurasian Journal of Business and Economics, 3(6), 113-125.

Zeithaml, A. Parasuraman, \& Arvind Malhotra (2000). A Conceptual Framework for Understanding E-Service Quality: Implications for Future Research and Managerial Practice, Working Paper, Report No. 00-115, Marketing Science Institute, Cambridge, MA. 